\title{
Tiding over the pandemic: The prospects of cruise tourism
}

\author{
Emil Mathew \\ Indian Maritime University, Chennai, India \\ emilameya@gmail.com
}




\title{
Tiding over the pandemic: The prospects of cruise tourism
}

\author{
Emil Mathew
}

Indian Maritime University, Chennai, India
emilameya@gmail.com

Received: 21/6/2021 Revised: 25/7/2021 Accepted: 30/7/2021 DOI: https://doi.org/10.31559/IJHTS2020.2.1.8

\begin{abstract}
Cruise tourism, which was achieving an average growth always higher than the global economic growth, had a global presence and saw participation from all the continents during this decade. The COVID-19 pandemic very adversely affected the global travel and tourism sector perhaps more than the other sectors of the economy. Since the time COVID-19 was declared a pandemic, in March 2020, the cruise tourism market went into a swift decline. The prospects of recovery of this market crucially hinges on how the pandemic is overcome and thereafter measures taken to rebuild confidence in the minds of the passengers. We present a sweep of cruise tourism in this paper covering the nature of the cruise market, demographic composition of passengers, challenges, and opportunities, and show the relevance of cruise tourism as an industry contributing to global tourism. We also dwell upon the internal and external risks and uncertainties experienced by the cruise industry. In the light of several measures taken all over the world to address the pandemic, we examine the measures taken by the cruise companies to rebuild the lost confidence as the cruise industry operates in an elastic market.
\end{abstract}

Keywords: cruise tourism; pandemic; global tourism; crisis of tourism.

\section{Introduction}

Cruise tourism, which represents only 02 per cent of the global travel industry, is a high-growth sector in the tourism industry, achieving an annual growth rate of 6.74 per cent. An estimated 28.5 million passengers travelled on cruises in 2018, compared to 26.7 million passengers in 2017 (CLIA, 2020). According to United Nations World Tourism Organisation (UNWTO) World Tourism Barometer, cruise tourism grew at 07 per cent in tourist arrivals in 2018 whereas international tourism grew at 06 percent in tourist arrivals (UNWTO 2019).

The huge cruise ships, often described as floating resorts, operate in deterritorialised environments, and cater to diverse entertainment requirements of the tourists by a global workforce serving on-board food, accommodation, entertainment, and shopping besides shore tourism (Najafipour 2014; Georgsdottir and Gunnar 2017; Santos 2019). The wide range of services offered in a single package on-board vessels compete with land-based tourist destinations and other entertainment avenues.

Operating on high seas, cruise tourism thrives on the trust and confidence assured by the cruise operators, as the travel packages typically involve a short-duration tour, lasting a few days, or a long-duration holiday, lasting a few months. Leaving the tour abruptly between ports is rather impossible once the vessel sets sail. The onus is on the operators to keep the passengers entertained throughout the tour. Avoiding contingencies and addressing unforeseen risks form a part of cruise operations. The unexpected can happen. Acts of terrorism, natural calamities, economic crisis, and medical emergencies haunt this sector from time to time (Sausmarez 2007; Wilks and Stewart 2004; Holland 2019; Bowen et al. 2014; Bysyuk 2010). The impact of all these unforeseen events was largely localised, low and confined to only a particular geography. But the COVID-19 pandemic poses unique challenges to the cruise industry. Lockdowns in the initial phase of the pandemic curbed movement of people, and tourism was nowhere in anyone's mind. Entertainment was totally curtailed as it poses an epidemiological risk. Further, the pandemic-induced financial crisis forced people to avoid non-essential services, especially tourism, the sector always with an elastic demand. Moreover, the lasting epidemiological risks and the difficulty to ensure safety and security to travellers in a cruise vessel increases the perceived risks of passengers. The very nature of this industry 
and confined spaces on-board make it difficult to ensure social distancing, one of the essential measures to stop the spread of COVID-19.

As the world battles the pandemic, which has had a negative impact on the global economy and relegated tourism to the brink, it would be pertinent to provide an overview of the historical evolution of cruise tourism, nature of the cruise industry and the demographic composition of the tourists to show how cruise industry formed an important part of tourism. How cruise tourism is negotiating the unforeseen effects of COVID-19 is also pointed out in this paper. Attention is focused on how major cruise tourism operators used their Web pages to revive the sector and instil confidence in international cruise tourist community to tide over the crisis. In conclusion, suggestions to revive the cruise industry that operates in an elastic market requiring a huge human involvement are provided.

\subsection{Cruise tourism: A brief historical roadmap}

The steamers that sailed to North America with thousands of Europeans during the first half of the 19th century were considered the forerunners of the modern-day cruise tourism, which took shape through a long journey of transformation of merchant ships and passenger ships in the 19th and early 20th centuries. The Cunard Steamships Limited's first steamship, Britannia, from Liverpool to Boston via Halifax with 63 passengers in 1840 was the first ocean liner with a recorded history of transporting passengers and cargoes (Ajagunna and Pinnock 2006). By the 1880 s, a significant growth in the vessels carrying passengers between Europe and North America had taken place with the introduction of steamships and shipping companies. Several luxury passenger ships launched during the same period, such as Aquitania and Leviathan of the Hamburg American Line and the Olympic, the Titanic and the Britannic of the White Star Line, offered luxurious services and had a high carrying capacity (Nguyen and Annaraud 2018). Many a time, these transatlantic vessels failed to ensure comfort and safety as passengers often met with accidents and succumbed to the fury of the oceans.

The First and Second World Wars interrupted marine transportation on the Atlantic Ocean as the passenger vessels were recommissioned to transport military troops (Stopford 2008). However, during this period, the laws passed by the US government pertaining to the prohibition in the sale of alcohol nationwide, issue of subsidies to build larger ships and the Immigration Act of 1917 gave impetus to the growth of US ocean liners (Byod 1999). What really pushed ocean liners into a shadow of its former self was the commercialisation of the airlines industry in 1960s. The transatlantic passenger transport shrunk to 5 per cent in 1969 (Stopford 2008). The rise in oil prices further dealt a blow to ocean liners, which lost popularity as a principal mode of passenger transport. These events eventually birthed dedicated cruise service as ocean liner companies converted their vessels for cruise travel, despite being handicapped by high costs, poor services, limited ship capacity and restricted ports of embarkation. In 1970, the North American passenger liner market served only 500,000 cruise passengers (Coggins 2014). Over the course of time, ocean liners attracted global tourists as they transformed from a mere mode of ocean transportation to offering the comfort of a resort with varied amenities.

In the mid-1970s, Carnival Cruise Lines first introduced the idea of cruise as a voyage for leisure on-board a vessel for visiting a variety of destinations rather than a set route (Ajagunna and Pinnock 2006; Nguyen and Annaraud 2018). Two other cruise operators, Royal Caribbean Cruise Line (RCCL) and Norwegian Cruise Lines, established during the same period, are still active in the cruise industry. Cruise liners from then on have improved upon their carrying capacity, offering more variety of services to the passengers, and adding safety measures. Scientific and technological advancement improved methods of navigation and communication, providing ocean liners the necessary wherewithal to combat environmental adversities. During 1980s, the cruise industry introduced mega ships with carrying capacity of more than 2000 passengers and incorporated on-board activities to make cruising a unique travel experience. The industry itself went through a process of consolidation through mergers and acquisitions. This has resulted in Carnival Corporation, Royal Caribbean and Norwegian Cruise Lines becoming the top three cruise companies in the world.

\subsection{Nature of the cruise market}

The cruise market operates mostly in three geographical regions: Europe, North America and Asian region. With a recorded utilisation of more than 100 per cent capacity, cruise industry is the fastest growing sector in the travel and tourism industry, which contributes 10.3 per cent to the global GDP, providing employment to 330 million people (WTTC 2019). The Cruise Lines International Association (CLIA 2018), an industry organisation of cruise liners, reports that 28.5 million passengers went on a cruise in 2018 alone, generating an estimated revenue of USD 45.6 billion for the cruise industry.

Cruise tourism offers luxurious on-board travel on a vessel with a variety of options for entertainment besides shore excursions and visits. Some studies (Bowen et al 2014; Singh 1999) have indicated that cruise tourism has become popular and affordable with the provision of all-inclusive products, debunking the perception of it as a luxury service. Cruise travel faces competition from land-based entertainment (Jeon et al 2019). According to Nguyen (2018), the cruise liners recruit crew from various countries to create an international environment in the vessel and often the employees work for longer hours at a lower wage. Accommodation offered on-board is like 
offshore facilities. Uysal and Jurowski (1994) examined on-board and offshore motivational factors of cruise tourism. On-board environment, recreation and social interactions were the major on-board factors whereas safety and comfort, learning and exploration, and visual appeal of the surroundings were the offshore factors that motivated the cruise decisions.

Cruise travel is offered in budget, contemporary and premium segments (Oskarsson and Irena 2017). Relatively small companies with older ships offer budget cruise travel, whereas contemporary sector is made up of largest demographic passenger group and large profits are realised from this sector due to economies of scale. Ultraluxurious cruise travel is offered to an elderly, elite segment of the population. These three sections form the mass market for cruise travel, over which lies the niche sector with highly diverse group of cruise options: sailing ships, high-end yachts, small cruise vessels with unusual itineraries, river cruises and various kinds of exploration, adventure, and special interest cruises. Therefore, through diverse cruise products and services, the cruise industry caters to a wide category of customers.

Cruise tourism comes under the leisure market where customers desire quality services to give them relaxation, hassle-free trip with flexibility, options to visit different destinations, luxurious and fun-filled vacation with fine dining and variety of high-quality entertainment (CLIA 2018). Cruise liners compete in offering a variety of services and to make cruise travel a quality experience. They offer a variety of options for passengers such as short cruises, cruises lasting several days, several weeks or more than a few months, thematic cruises, cruises around the world, expedition cruises, etc. (Perucic 2019).

Table 1 lists the dominant players in cruise tourism detailing the number of ships with their carrying capacities.

Table (1): The 15 top ranking cruise shipping companies in 2017

\begin{tabular}{|c|c|c|c|c|c|c|c|}
\hline Owner/Operator & Country & No & $1000 \mathrm{gt}$ & Berths & Avg1000gt & Gt\% share & Average age \\
\hline Carnival & USA & 103 & 8959 & 229655 & 87 & 43.0 & 13.6 \\
\hline RCCL & USA & 39 & 4410 & 107811 & 113 & 21.2 & 14.3 \\
\hline NCL Group & USA & 25 & 2077 & 50475 & 83 & 9.9 & 11.7 \\
\hline Mediterranean Shipping & Switzerland & 14 & 1520 & 40396 & 109 & 7.3 & 9.8 \\
\hline TUI Group & Germany & 16 & 940 & 24166 & 59 & 4.5 & 19.8 \\
\hline Genting Group & Malaysia & 9 & 681 & 16420 & 76 & 3.3 & 19.7 \\
\hline Disney Cruise Line & USA & 4 & 426 & 8520 & 107 & 2.0 & 12.0 \\
\hline Viking Ocean Cruises & Norway & 4 & 192 & 3712 & 48 & 0.9 & 1.2 \\
\hline Silversea Cruises & Italy & 9 & 183 & 2864 & 20 & 0.9 & 20.8 \\
\hline $\begin{array}{l}\text { Cruises and } \quad \text { Maritime } \\
\text { Voyages }\end{array}$ & UK & 5 & 169 & 4628 & 34 & 0.8 & 50.7 \\
\hline Friend Olson Cruise Line & Norway & 4 & 125 & 3785 & 31 & 0.6 & 35.2 \\
\hline Phoenix Reisen, Bonn & Germany & 4 & 124 & 3154 & 31 & 0.6 & 30.2 \\
\hline Louis Group & Cyprus & 4 & 98 & 3940 & 25 & 0.5 & 33.2 \\
\hline Sky Sea Cruise Line & China & 1 & 72 & 1778 & 72 & 0.3 & 21.7 \\
\hline Windstar Cruises & UK & 6 & 56 & 1234 & 9 & 0.3 & 27.9 \\
\hline Others & & 60 & 794 & 21980 & 13 & 3.8 & 27.0 \\
\hline Total & & 307 & 20827 & 524518 & 68 & 100.0 & 17.2 \\
\hline
\end{tabular}

Source: ISL Shipping Statistics and Market Review 2017.

Almost 75 per cent of the cruise market in 2017 was dominated by three players: Carnival, which has a major share of the gross tonnage, followed by RCCL and NCL, occupying the second and third positions. Thus, cruise tourism market is oligopolistic, with a few major players predominantly deciding the course of the market, the types of the services offered and the prices. Heavy capital investment needed for purchasing cruise ships and maintaining the services at a high-cost act as a barrier to entry to the industry. Similarly, the limited number of ship builders reduce the bargaining position of cruise liners whereas the wide presence of suppliers of equipment, fuel and food products improve their competitiveness.

The cruise industry, earlier mostly preferred by elderly wealthy couples, gradually underwent a transformation in demographic composition and also in regional representation (Georgesdottir and Gunnar 2017). According to CLIA, the average age of a cruiser was 47 years and the average number of days of cruise was 7.2 days in 2017. The rate of growth in arrivals of cruise tourism is more than the rate of growth achieved by travel and tourism over the years. The annual growth of global cruise passengers given in Table 2 indicates a significant growth over the decade.

Table (2): Global Ocean Cruise Passengers (in Million)

\begin{tabular}{lcc}
\hline Years & Passenger capacity & Annual growth rate (\%) \\
$\mathbf{2 0 0 9}$ & $\mathbf{1 7 . 8}$ & - \\
\hline 2010 & 19.1 & 7.30 \\
2011 & 20.5 & 7.33 \\
2012 & 20.9 & 1.95 \\
2013 & 21.3 & 1.91 \\
2014 & 22.34 & 4.88 \\
2015 & 23.06 & 3.22 \\
2016 & 25.2 & 9.28 \\
2017 & 26.7 & 5.95 \\
2018 & 28.5 & 6.74 \\
$2019 P$ & 30 & 5.26 \\
$2020 P$ & 32 & 6.66 \\
\hline
\end{tabular}

Source: State of the Cruise Industry Outlook 2020, CLIA. 
Caribbean region, which commands 40 per cent of the worldwide cruise market, has a high deployment followed by Mediterranean and Europe (Cruise Industry News 2019). North American passengers constituted 50 per cent of the cruise passengers of 2018, followed by passengers from West Europe and Asia. Though number of cruise passengers from North America increased from 5.05 million in 1997 to 14.24 million in 2018, the relative share of North America in the total market has declined from 73.5 per cent to 50.2 per cent during the same period (CLIA 2020; Perucic 2019). Asian ocean cruise passengers recorded the highest growth rate with 20.5 per cent, whereas the European passenger market attained a saturated growth rate with 2.5 per cent (CLIA 2017). Asia seems to be potential future cruise market going by its recent growth.

Asian cruise tourism market is relatively new and 80 per cent of Asian cruisers prefer shorter trips of two to six days. A study on the willingness to pay by Asian cruisers, carried out by Chen et. al (2016), showed out that the variables such as income, education, family structure, occupation, cruise experience, cruise duration and cruise preferences were associated with willingness to pay. The observations from this study could be used for pricing and offering services across different segments of the cruise industry. A study on the recent trends in the cruise market in China by Liu et al. (2020) pointed out that the newly retired senior citizens with leisure time and money have a strong desire to take cruise trips. The cruise trips offering packages focusing on the kids and parents are likely to be desired by Chinese tourists who prefer to expose their kids to new experiences. The options for shopping and the availability of tour guides are other travel experiences highly valued and preferred by them. Summing up what passengers from Asia want, Chen et al. (2019) notes that cruise vessels serve as hybrid platforms, both acting as suppliers of ship-based products and services and serving as promoters of cruise ports' itineraries.

Diverse experiences gained from a single voyage that includes different destinations is beneficial in saving money and time and at the same time minimises the risks and uncertainties associated with making separate trips (Holland 2019). By providing entertainment opportunities on the vessel, these floating resorts try to maximise cruisers' time spent on-board, minimising the time spent in the port. Thus, cruise ship companies directly compete with the offshore facilities offered at the port to attract passengers and it is seen that cruisers prefer to purchase imported luxury goods with little local content (McKee 1988; Seidl 2006). A study by Pattullo (1996) points out that in the Caribbean region, some cruise companies own islands, cays or beaches, thereby minimising contacts with the local community and avoiding the sharing of expenditure with an outside local economy. Of the 28 cruise destinations in Caribbean, 12 are owned by cruise companies. These enclosed entertainment zones in private islands are the captive markets completely controlled and run by the cruise companies (Ajagunna and Pinnock 2006).

Cruise tourism does not benefit the local economy as a study on the economic impact of cruise tourism on the local economy in Costa Rica shows. When the spending of the cruisers and crew of the vessels on the local products is compared with the imported products available on the shore and also on-board, it is shown that the money injected into the local economy per cruise tourist is substantially lower than other types of tourism (Seidl 2006). The all-inclusive packages offered by the cruise vessels with no avenues to spend on the local community brings down the multiplier effects that the cruise ships are expected to generate.

A study on the motivations for cruise carried out by Jones (2011) indicates that the cruise experience attracts the passengers and not the itinerary. The personal and internet-based information sources act as major sources influencing the passengers' desire to travel. A study carried out by Fox, a criminologist in 2018, brought to the light that crime rates in cruise vessels are 25 times lower than land tourism due to the strict compliance of comprehensive security regulations since embarkation, the deployment of highly trained security personnel, transparency in crime reporting and ensuring strict compliance through a published list of prohibited items (Goldstein 2019). A study by GP Wild International in (2019) covering 10 years from 2009 to 2018 indicates a reduction in operational incidents and rate of human incidents, though there has been a 55 per cent growth in cruise passengers during the period (Sampson 2019). The cruise liners have been able to achieve this progress by giving crew member training, scrutiny of ships, constant improvements of safety procedures and technology and also by adopting adequate precautionary measures.

Certain studies have examined the burden of the negative environmental consequences that cruise tourism foists on the local community and also on the marine environment. A cruise vessel with more than 3000 passengers and crew is estimated to generate 210,000 gallons of sewage, 1 million gallons of greywater, more than 130 gallons of hazardous wastes, 8 tons of solid waste and 25,000 gallons of oily bilge water (Copeland 2005). According to Najafipour et al. (2014), major cruise lines have taken steps to minimise the adverse effects they leave on the environment such as air pollution, illegal dumping of sewage and solid waste, inadequate treatment equipment, damage to coral reefs and sensitive marine environments. The studies that examined cruise tourism from the sustainability perspective have focused on how cruise liners can ensure environmental, social and local sustainability while meeting the needs of the present generations without compromising the needs of the future. A study by Klein (2011) invokes the concept of responsible tourism to explain the role of a balanced and an equitable sharing of the welfare across cruise liners and all the other stakeholders, particularly among the local community without leaving any negative environmental effects. Cruise tourism also has the responsibility to minimise the negative sociocultural impacts. Large-scale cruise visits to destinations produce unfavourable overcrowding, 
leading to lower sociocultural experience, cultural degradation and community disruption. Pinnock (2012) stated that the large cruise vessels do not always bring economic returns to the local community and rather, there is an inverse relation between the size of the cruise and the positive economic gain to the community.

\subsection{Uncertainties and challenges faced by the cruise market}

The major uncertainties and the risks faced by the cruise liners have been classified into internal and external. But Ugur and Akbiyik (2020) used the terms endogenous and exogenous to classify the point of origin of crisis and threats, as the former indicates the source from within whereas the latter indicates that the source of these threats lie outside. Endogenous crises could be prevented easily as human or technological factors that contribute to such crises can be managed more effectively whereas exogenous crises are rooted in the external environment and hence outside the influence of the cruise liner company. The internal risks could be related to the outbreak of fire accidents, shortage in the supply of goods, dissatisfaction of passengers or any conflict taking place on-board. External uncertainties affecting the tourism are wars, terrorist attacks, natural disasters, epidemics and financial crises (Tekin 2015). The 9/11 terrorist attacks and the Global Financial Crisis of 2008 reduced global mobility and had a significant impact on the global economy.

Rodrigue and Wang (2020) pointed out that the risk of hurricanes due to climate change in the Caribbean would disrupt sustainable cruise supply chain. Thus, the floating resorts must be resupplied during their short port rotations by customised procurement practices. The unforeseen events could result in uncertainty of on-board consumption and hence the cruise liners are required to ensure the replenishment of a ship to maintain the quality of the on-board experience. The main categories include suppliers of navigational equipment and fuel, product suppliers for accommodation, merchandise suppliers for retail outlets and food suppliers for restaurants and bars. Theseasonality, expected consumption behaviour, along with demographic composition of the passengers onboard, determine the orders. The weather-induced disruptions leading to uncertainties in the cruise supply chain necessitates the management to be prepared for any eventuality. The flexibility and adaptability of the cruise industry to rise up to the situation is suggested to address the uncertainty.

Lack of safety at the destinations impact the travel decisions of the tourists (Dreyer et al 2010). Kozak et al. (2007) pointed out that it is not the real risks, but often the perceived risks emanating from fear of disease, lack of sanitation, natural disaster or political dispute influence the travellers to change their travel plans. According to Bysyuk (2010), the terrorist attack in the USA affected the travel and tourism industry and a decrease in demand was experienced by all sub-industries such as travel, hospitality, leisure, and restaurant. The negative effects of the terrorist attack continued for 6 to 25 months depending on the industry. Similarly, some tourists cancelled their trips to USA and travelled to safer destinations.

Tekin (2015), through his study on the tourism market in Turkey, determined how demand for the tourism market is interrelated with international issues. He stated that the political tension between the EU and Russia led to decreasing number of Russian tourist arrivals to the $\mathrm{EU}$ and it contributed positively to an inflow of Russians to Turkey, though the state was experiencing political and economic instability. An analysis on the time taken for recovery during the previous crises having global implications indicate that worldwide arrivals returned to normal growth five months after 9/11 and five months after the SARS outbreak in 2003, whereas it took 10 months to regain growth after the Global Financial Crisis of 2008 (WT Barometer 2020).

Contact with international tourists increases the chances of disease, which appeared to be more than the chance of an individual getting the disease from his domestic state. In the destinations the tourists travel to, their contact with pathogens, bacteria, parasites and viruses that are no longer to be found in their home countries increases the rate of sickness (Ugur and Akbiyik 2020). The health characteristics of individuals, especially people with comorbidities, are prone to health emergencies compared to others. Travellers generally choose a destination depending on the safety and security at the preferred location (Kuschel and Schroder 2002). In 2003, the SARS epidemic spread to 30 countries and infected 8000 people. However, the spread of the disease could be prevented to a great extent because of the travel restrictions issued by the WHO. The economies that relied heavily on tourism were the worst affected and the economic ramifications reduced the GDP of many Asian economies. China's GDP fell by 25 per cent, Vietnam's by 15 per cent, and that of Hong Kong and Singapore by more than 40 per cent compared to the previous year (Richie 2009). One of the studies (McKercher and Chon 2004) stated that the overreaction to pandemic is the major reason behind the collapse of Asian tourism.

\subsection{Impact of COVID-19 on the cruise industry and the long road to recovery}

It is evident from the preceding discussion that cruise industry is highly prone to various exogenous challenges including terrorism, economic slowdown and infectious diseases. However, the challenge posed by COVID-19 is unprecedented and has had a devastating effect on the cruise industry. Given the magnitude of the epidemic and its long-lasting impact, this crisis is unparalleled in the history of modern cruise industry. Revised OECD estimates on the impact of COVID-19 indicate that international tourism declined by 60 per cent in 2020 but expected to further drop by up to 80 percent if the pandemic situation exists beyond December 2020, which would imply a loss of USD 910 billion to USD 1.2 trillion in export revenue from tourism. The World Travel and Tourism Council made a 
forecast that 100.8 million jobs are at risk and the ILO policy brief identified tourism as the most vulnerable sector that is likely to experience a drastic fall in the jobs due to COVID-19 pandemic (OECD 2020). Various studies (Radic et al 2020; Jenness et al 2020) that focused on the impact of COVID-19 on travel and tourism have analysed the intensity of the crisis on tourism industry by examining the immediate reaction of the travellers and tour operators. The UN Secretary General Antonio Guterress (UNWTO 2020), in his statement, mentioned that the first five months of the pandemic reduced the international tourist arrivals by half and reduced the exports from tourism by USD 320 billion. About 120 million direct jobs in tourism are at risk, especially the women, rural communities, indigenous people and many historically marginalised people are the most affected. Asia and the Pacific saw a decrease of 35\% in arrivals in Q1 of 2020. The second hardest hit was Europe with a 19\% decline followed by Americas (-15\%), Africa $(-12 \%)$ and the Middle East (-11\%) (WTO Barometer 2020). According to UNWTO, domestic tourism will recover faster than international tourism. An impact assessment study (Ugur and Akbiyik 2020) of the COVID-19 pandemic using text mining by analysing the comments of travellers and travel planners revealed that tourism sector is very sensitive and easily affected by a global crisis. On the day WHO declared COVID-19 a pandemic, many travellers cancelled their trips immediately and started to discuss travel assurance issues.

Cruise industry came to an abrupt stop with the onset of the pandemic as passengers who booked upcoming cruise trips resorted to mass cancellation. Cruise ship companies themselves cancelled bookings and stopped further cruise announcements. The focus immediately shifted to cruise ships that were on the waters as COVID-19 cases began to be reported from these ships or from passengers who disembarked from these ships. Given the congested spaces within a cruise ship and the difficulty in practicing social distancing, these vessels were seen as the potential breeding grounds of COVID-19 and were denied permission to call on the ports and disembark tourists. These ships were forced to travel from ports to port, seeking permission to dock, or were anchored near the shore indefinitely awaiting permission to disembark. The news reports of such vessels became an international sensation as the plight of the stranded passengers was discussed widely. The most prominent was the case of Diamond Princess (Statista 2020), which had set on sail on 20 January 2020 from Yokohama, Japan, with a crew of 1045 and 2666 passengers on-board. A week later, a passenger who disembarked in Hong Kong tested positive for COVID-19 and the authorities informed the cruise company of the impending danger. However, it is alleged that the ship management continued with the regular entertainment and other activities on-board without informing the passengers of the imminent risk. Later, on 5 February 2020, Diamond Princess was quarantined in Yokohama and the guests and the crew were tested. Japanese authorities made elaborate facilities to evacuate the infected tourists and provide them with adequate medical care on the shore. Other passengers were asked to undergo quarantine on the ship and it was a real hard time for them to be confined into small cubicles inside the ship under tiring conditions of anxiety and fear. By $1 \mathrm{March}$, all passengers and cruise members were allowed to disembark, and arrangements were made for their onward journey to their respective countries. It is estimated that as of $27 \mathrm{March}, 712$ of the 3711 passengers on Diamond Princess had tested positive for COVID-19, out of which 9 people had died. It is certain that the tragedy on-board of Diamond Princess will loom large over the cruise industry for years to come and likely to influence future passengers.

This incident was followed by several similar incidents reported from several cruise circuits (Zdanowicz 2020). MS Braemar, a UK-owned cruise vessel, was stranded in the Bahamas and was denied entry at several ports in the Caribbean due to reported COVID-19 cases on-board. Four passengers and one crew member, including a doctor, were placed under isolation after they were observed to be having symptoms. A cargo carrier delivered supplies of food, medication and other essentials to the ship and hence averted a serious shortage of essential supplies on-board. In another incident, Silver Shadow, docked in isolation in north-eastern Brazil, had two guests who tested positive and one among them was an elderly person. In yet another case, the Silver Explorerwas docked in Chile after a passenger tested positive for COVID-19, and the ship was put in quarantine off the port of Castro. The passengers of Golden Princess, a vessel carrying 2600 passengers and $1100 \mathrm{crew}$ near Akora harbour in New Zealand, were denied permission to disembark after three passengers developed symptoms. The Norwegian Jewel in the Pacific Ocean was denied docking at the previously scheduled ports in New Zealand and Australia, though there were no suspected or confirmed cases of COVID-19. The Pacific Princess, which embarked on its 111 days' voyage in January, announced closure of its operations within 60 days due to COVID-19-related fears as it was denied entry to scheduled ports and so disembarked guests at convenient locations. Three passengers with symptoms of COVID-19 disembarked in Spain's Canary Islands, from the Costa Luminosa, a Carnival Corporation owned vessel, though Spain had banned all cruise operations since 12 March. Each of these incidents, widely telecast and reported across the world, highlighted the depth of the crisis that the cruise industry found itself saddled with The disturbing images of stranded ships and locked-up passengers who once boarded the ship for luxurious leisure time became the death knell of the cruise industry at the time of a pandemic.

According to Ugur and Akbiyik (2020) the COVID-19 pandemic had produced its effects both on the demand and supply sides of the tourism. On the demand side, restrictions were imposed on the freedom of movement, border closings, guests' fear of infection, whereas on the supply side the closure of accommodation, catering establishments and leisure facilities used for tourism halted the operations of travel and tourism. Given the confined nature of space in a cruise liner where guests are forced to interact with each other and where the crew members 
stay in proximity makes the cruise industry the last option for potential tourists looking for a welcome change from the monotony of complete lockdown. However, cruise companies, already suffering massive losses and staring at an uncertain future, has started initiating measures to revive the industry.

Cruise liners have adopted several measures to rebuild the confidence of passengers by enforcing safety and security norms besides updating their websites with flexible booking and cancellation options. The measures currently put forth by the cruise industry can be divided into three broad heads: prevention, mitigation, and response measures. Royal Caribbean and Norwegian's Healthy Sail Panel published 74 recommendations to the Centre for Disease Control and Prevention with an intention to prevent the introduction and mitigate the spread of COVID-19 on cruise ships (Hines 2020). It includes the best practices to safeguard and protect the health of the passengers, crew and the community that they visit. The protocol details would be worked out by each company and CDCP will ultimately decide appropriate guidelines once cruising companies resume their operations. The key areas that the report focused upon includes testing, screening, and exposure reduction; sanitation and ventilation; response, contingency planning and execution; destination and excursion planning; and mitigating risks for crew members. An exhaustive plan has been chalked to bring passengers, crew and local community under the purview of safety measures, which indicates the level of concern and care extended towards human life. The initiatives taken by the cruise liners to implement the best practices to regain the confidence of the tourists will be strengthened once cruise tourism operations resume.

The cruise liners have offered flexible booking options on their websites, which consists of request for a refund, lift and shift the plan to a future date and future cruise credit to book a new cruise. TUI Cruises and Hapag Lloyd (TUI Group 2020) produced a 10-point plan to reassure passengers and encourage more people into travelling again. Among these points are pre-boarding thermal image screening for travellers; social distancing; 40 per cent less guests; reduced table numbers in the restaurants; fewer participants in sports and entertainment activities; ships equipped with a laboratory and expanded medical teams. Crew members will undergo regular screening for COVID-19. Elderly people older than 70, who constitute a major segment of the passengers, are asked not to take cruises. Jenness et al. (2020) state that extreme restrictions in contact patterns during the network lockdown and idealistic clinical response scenarios could only avert a major outbreak of COVID-19. A change in the behavioural intervention and clinical diagnosis are necessary to prevent a massive impact of an outbreak. Limited passenger crew contacts for the crew and an early screening with PCR test and isolation of the individual upon diagnosis are suggested for the passenger. Cruise ship environment is the one in which the potential for critical transmission is very high. There have been several incidences of epidemic outbreaks in the cruise ships in the past. The denial of access to the ports and the medical facilities on-board to the infected passengers resulted in additional infections and psychological distress to the passengers and the crew. The reputational damage faced by the industry could be restored only if they adopt improved public health standards, resort to aggressive marketing and offer massive discount.

\section{Conclusion}

Cruise industry is a niche market in the travel and tourism industry catering to the more affluent sections of the tourists. This travel segment was witnessing an impressive growth over these years, but the outbreak of COVID19 has dealt a deadly blow to the cruise industry. While external threats such as terrorism, accidents or economic meltdown are not new to the cruise industry, the challenge posed by COVID-19 is unparalleled in terms of its immediate as well as long-term impact on the whole business. The very nature of cruises where the passengers are forced to interact with each other and with the crew in limited spaces makes cruises extremely vulnerable to the spread of this pandemic. The tragic stories of COVID-19-affected cruise liners anchored indefinitely near the ports, not able to disembark the passengers, will linger in the minds of potential travellers for a long time.

The resolution to COVID-19 challenge to the cruise industry will emerge only as a part of the larger story of the triumph of humankind over this deadly pandemic. Invention of effective vaccines and its widespread administration to a sizeable section of population alone will decidedly end the onslaught of the pandemic. While cruise companies have initiated several measures to regain the confidence of customers and resume the voyages, it is yet to be seen how many tourists would express interest in tourism activity in an uncertain environment. Given the availability of a host of inland tourism options, cruise tourism will be one of the last options for the travellers due to its very limitations in terms of space on-board and high density of people in a given area. Considering the nature of the market with potential difficulties, the recovery of cruise industry from COVID-19 appears to be a slow and painful process. However, the growing participation of cruise tourists from various continents during earlier outbreaks and uncertainties indicate that regaining the lost cruise market is not very difficult, if the industry is ready to welcome them with attractive price discounts and safety measures. 


\section{References}

1. Ajagunna, Ibrahim \& Fritz, Pinnock (2006). Challenges for Cruise Industry and Port City Governance: The Case of the Caribbean, Capsule Professionelle 6, Partie II Retors d Experiences Internationals.

2. Bowen, Clare, Paul, Ronals Fidgeon \& Stephen John, (2014). Maritime Tourism and Terrorism: Customer Perceptions of the Potential Terrorist Threat to Cruise Shipping, Current Issues in Tourism, 17 (7): 610-639, https://doi.org/10.1080/13683500.2012.743973.

3. Byod, Lydia (1999). Brief History of Passenger Ship Industry, Duke University, https://library.duke.edu/specialcollections/scriptorium/adaccess/ship-history.html.

4. Bysyuk, Veronika (2010). Impact of 9/11 Terrorist Attacks on US and International Tourism Development. Thesis submitted to obtain a bachelor's degree in Business Administration Tourism and Hospitality Management, Modul Vienna University.

5. Chen, Jamie M, Junzhou, Zhang, \& Peter, Nijkamp (2016). A Regional Analysis of Willingness to Pay in Asian Cruise Markets, Tourism Economics, 22(4): 809-824, https://doi.org/10.1177/1354816616654254.

6. Chen, Jamie, M, Mark, G. Lijesan \& Peter, Nijkamp (2017). Interpretation of Cruise Industry in a Two-Sided Market Context: An Exploration on Japan. Maritime Policy and Management, 44(6):790-801, https://doi.org/10.1080/03088839.2017.1335898.

7. CLIA, (2018). State of the Industry, Cruise Industry Outlook, https://cruising.org/-/media/researchupdates/research/featured/2018-clia-state-of-the-industry.pdf.

8. CLIA, (2020). State of the Cruise Industry Outlook, USA. https://cruising.org/-/media/research-updates/research/state-of-thecruise-industry.ashx.

9. CLIA, (2020). State of the Cruise Industry Outlook.

10. Coggins, Jr Andrew Oscar (2014). The Globalisation of the Cruise Industry: A Tale of Ships, Worldwide Hospitality and Tourism Themes 6(2): 138-151, https://doi.org/10.1108/whatt-12-2013-0048.

11. Copeland, Claudia (2005). Cruise Ship Pollution: Background, Laws and Regulations, and Key Issues, CRS Report for Congress.

12. Covid-19 Recommendations to CDC, USA Today, https://www.usatoday.com/story/travel/cruises/2020/09/21/norwegian-royalcaribbean-cruise-panel-suggests-covid-19-rules/5839739002/.

13. Cruise Industry News (2019). Annual Reports 2019, https://www.cruiseindustrynews.com/store/product/annual-reports/2019cruise-industry.

14. G. P. Wild International (2019). Cruise Industry Statistical Review 2018-19, UK.

15. Georgsdottir, Iyrene \& Gunnar, Oskarsson (2017). Segmentation and Targeting in the Cruise Industry: An Insight from Practitioners Serving Passengers at the Point of Destination, The Business and Management Review, 8 (4): $350-364$.

16. Goldstein, Michael (2019). Is Cruise Ship Crime Continuing to Climb?, Forbes, Dec 9, 2019.

17. Hines, Morgan (2020). Tests, Masks, Temperature Checks: Healthy Sail Panel Submits 74

18. Holland, Jennifer (2019). Navigating Uncertainty: Tourists Perceptions of Risk in Ocean Cruising. PhD Thesis, University of Brighton.

19. ISL Shipping Statistics \& Market Review (2017). Shipping Statistics and Market Review, 61(8), Institute of Shipping Economics and Logistics, Bremen.

20. Jenness, Samuel, Kathryn, S Willebrand \& Amyn, Malik (2020). Modeling Dynamic Network Strategies for SARS-CoV-2 Control on a Cruise Ship, https://doi.org/10.1101/2020.08.26.20182766.

21. Jeon, J.W., O. Duru \& G.T. Yeo (2019). Cruise Port Centrality and Spatial Patterns of Cruise Shipping in the Asian Market, Maritime Policy \& Management, 46 (3): 1-20, https://doi.org/10.1080/03088839.2019.1570370.

22. Jones, Rory Victor (2011). Motivations to Cruise: An Itinerary and Cruise Experience Study. Journal of Hospitality and Tourism Management, 18(1): 30-40, https://doi.org/10.1375/jhtm.18.1.30.

23. Klein, Ross A. (2011). Responsible Cruise Tourism: Issues of Cruise Tourism and Sustainability. Journal of Hospitality and Tourism Management, 18(1):107-116, https://doi.org/10.1375/jhtm.18.1.107.

24. Kozak, Metin, John, C Crotts \& Rob, Law, (2007) The Impact of the Perception of Risk on International Travellers, International Journal of Tourism Research, 9 (4): 233-242, https://doi.org/10.1002/jtr.607.

25. Liu, Yanhong, Erwei, Dong, Shiqi, Li \& Xiaowen, Jie, (2020). Cruise Tourism for Sustainability: An Exploration of Value Chain in Shenzhen Shekou Port. Sustainability, 12(7): 3054, https://doi.org/10.3390/su12073054.

26. McKee, David, L., (1988). Some Reflections on Cruise Ships and the Economic Development of Small Island Nations. Canadian Journal of Development Studies, 9(2): 249-259, https://doi.org/10.1080/02255189.1988.9670224.

27. McKercher, B. \& Chon, K. (2004). The Over-reaction to SARS and the Collapse of Asian Tourism. Annals of Tourism Research, 31 (3): 716-719. https://doi.org/10.1016/j.annals.2003.11.002. 
28. Najafipour, Amir Abbas, Vahid Marzi \& Mohammed Hossein Foroozanfar, (2014). The Future of Cruise Ship Tourism Industry: The Challenges of Cruising Market and Operations Management. Journal of Social Issues and Humanities, 2 (7).

29. Nguyen, Yen, \& Katerina, Annaraud, (2018). Evolution and Trends in US Cruise Industry, Global Overview of Research in Tourism. Hospitality and Leisure Management: An Online International Research Journal, 4(1).

30. OECD (2020). Tourism Policy Responses to the Coronavirus (Covid 19), https://read.oecd-ilibrary.org/view/?ref=124 1249847uf8nm95se\&title=Covid19_Tourism_Policy_Responses.

31. Oskarsson, Gunnar \& Irene, Georgsdottir, (2017). Marketing Communication towards Cruise Ship Passengers: The Implications of Market Segmentation. Tímarit Um Viðskipti Og Efnahagsmál, 14(1): 43, https://doi.org/10.24122/tve.a.2017.14.1.3.

32. Pattullo, Polly (1996). Sailing into the Sunset: The Cruise Ship Industry (156-177). In Last Resorts: The Cost of Tourism in the Caribbean, Cassel: London.

33. Perucic, Doris, (2019). Analysis of the World Cruise Industry, DIEM (1).

34. Pinnock, F, (2012). Caribbean Cruise Tourism: Power Relations Among Stakeholders (Paperback), May 2012. LAP Lambert Academic Publishing, Germany. ISBN10: 3659126446.

35. Radic, Aleksandar, Michael, Luck, Antonio, Ariza-Montes \& Heesup, Han (2020). Fear and Trembling of Cruise Ship Employees: Psychological Effects of the Covid 19 Pandemic. International Journal of Environmental Research and Public Health, 17(18) 6741, https://doi.org/10.3390/ijerph17186741.

36. Ritchie, Brent J.R., \& Simon, Hudson (2009). Understanding and Meeting the Challenges of consumer/ Tourist Experience Research. International Journal of Tourism Research, 11(2):111-126, https://doi.org/10.1002/jtr.721.

37. Rodrigue, Jean-Paul \& Grace, W.Y. Wang, (2020). Cruise Shipping Supply Chains and the Impacts of Disruptions: The Case of the Caribbean. Research in Transportation Business and Management, 100551, https://doi.org/10.1016/j.rtbm.2020.100551.

38. Sampson, Hannah, (2019). Is Cruising Safe? Most of the Time, but Beware of What Can Go Wrong, The Washington Post, July 18, 2019.

39. Santos, Maria, Elena, Radicchi \& Patrizia, Zagnoli, (2019). Port's Role as a Determinant of Cruise Destination Socio-Economic Sustainability. Sustainability, 11(17): 4542; doi:10.3390/su11174542.

40. Sausmarez, Nicolette de, (2007). Crisis Management, Tourism and Sustainability: The Role of Indicators. Journal of Sustainable Tourism, 15(6): 700-714, DOI: 10.2167/jost653.0.

41. Seidl, Andy, Fiorella, Guiliano \& Lawrence, Pratt, (2006). Cruise Tourism and Community Economic development in America and Caribbean: The Case of Costa Rica. PASOS, Revista de Tourismo y Patrimonio Cultural, 4(2): 213-224, https://doi.org/10.25145/j.pasos.2006.04.015.

42. Singh, A, (1999). Growth and development of the cruise line industry in Southeast Asia. Asia Pacific Journal of Tourism Research, 3 (2): 24-31, https://doi.org/10.1080/10941669908722016.

43. Statista Research Department, (2020). Covid 19 Patients on Diamond Princess Japan 2020, https://www.statista.com/statistics/1099517/japan-coronavirus-patients-diamond-princess/.

44. Stopford, Martin, (2008). Maritime Economics $3^{\text {rd }}$ edition, London: Routledge.

45. Tekin, Ebru, (2015). The Impacts of Political and Economic Uncertainties on the Tourism Industry in Turkey. Mediterranean Journal of Social Sciences, 6 (2): S5, https://doi.org/10.5901/mjss.2015.v6n2s5p265.

46. TUI Group, (2020). Hapag-Lloyd Cruises to Resume cruises with a Ten Point Health Plan and New Cruise Routes, https://www.tuigroup.com/en-en/media/press-releases/2020/2020-07-09-hlc-hapag-lloyd-cruises-to-resume-cruises.

47. Ugur Naciye Guliz \& Adem Akbiyik, (2020). Impacts of Covid 19 on Global Tourism Industry: A Regional Comparison. Tourism Management Perspectives, 36(2020): 100744, https://doi.org/10.1016/j.tmp.2020.100744.

48. UNWTO, (2019). International Tourist Arrivals Reach 1.4 Billion Two Years Ahead of Forecasts, https://www.unwto.org/global/press-release/2019-01-21/international-tourist-arrivals-reach-14-billion-two-years-ahead-forecasts.

49. UNWTO, (2020). https://www.unwto.org/tourism-covid-19.

50. Uysal, Muzzafar \& Claudia, Juriwski (1994). Testing the Push and Pull Factors, Annals of Tourism Research, 21(4):844-846, https://doi.org/10.1016/0160-7383(94)90091-4.

51. Wilks, Jeff \& Stewart, Moore (2004). Tourism Risk Management for the Asia Pacific Region: An Authoritative Guide for Managing Crises and Disasters, APEC, Commonwealth Australia.

52. WTO Barometer, (2020). UNWTO World Tourism Organization, 18(5): August-September 2020.

53. WTTC, (2019). Economic Impact Reports, https://wttc.org/Research/Economic-Impact.

54. Zdanowicz, Christina (2020). Multiple Cruise Ships are Left Stranded as Coronavirus Cases Increase, CNN Travel, $17^{\text {th }}$ March 2020, https://edition.cnn.com/travel/article/cruise-ships-stranded-coronavirus-trnd/index.html. 